Editorial

\title{
The European Refugee Controversy: Civil Solidarity, Cultural Imaginaries and Political Change
}

\author{
Robin Vandevoordt ${ }^{1,2, *}$ and Gert Verschraegen ${ }^{2}$ \\ ${ }^{1}$ Refugee Studies Centre, University of Oxford, Oxford, OX1 3TB, UK; E-Mail: robin.vandevoordt@qeh.ox.ac.uk \\ 2 Department of Sociology, University of Antwerp, 2000 Antwerp, Belgium; E-Mail: gert.verschraegen@uantwerpen.be \\ * Corresponding author
}

Submitted: 5 June 2019 | Published: 27 June 2019

\begin{abstract}
In the summer of 2015, a wave of solidarity washed across the European continent as 1.3 million refugees arrived. While many recent studies have explored how 'ordinary' men and women, NGOs and governments momentarily reacted to the arrival of refugees, this issue examines whether the arrival of refugees and the subsequent rise of civil support initiatives has also resulted in more structural cultural and political changes. The contributions assembled in this issue all delve into the enduring implications of Europe's 'long summer of migration'. They address four sites of change: the dynamics between civil and state actors involved in refugee protection; the gradual politicisation of individual volunteers and organisations; the reproduction of pre-existing cultural imaginaries; and the potential of cities to foster new forms of solidarity.
\end{abstract}

\section{Keywords}

asylum; civil society; Europe; politicisation; refugees; refugee protection; solidarity; volunteering

\section{Issue}

This editorial is part of the issue "The European Refugee Controversy: Civil Solidarity, Cultural Imaginaries and Political Change", edited by Gert Verschraegen (University of Antwerp, Belgium) and Robin Vandevoordt (University of Oxford, UK/University of Antwerp, Belgium).

(C) 2019 by the authors; licensee Cogitatio (Lisbon, Portugal). This article is licensed under a Creative Commons Attribution 4.0 International License (CC BY).

\section{Introduction}

When Europe experienced the 'long summer of migration' in 2015 (Hess et al., 2016), its governments seemed neither ready nor prepared. In the absence of adequate protection organised by the state, citizens and NGOs stepped in and provided stop-gap help to the newly arriving refugees. Since then, numerous studies have appeared on the rise of civil solidarity in the wake of Europe's 'long summer of migration' (e.g., della Porta, 2018; Feischmidt, Pries \& Cantat, 2019; Sutter \& Youkhana, 2017). Yet few have detailed its enduring effects on civil solidarity, cultural imaginaries and political structures. Rephrasing Sydney Tarrow's (2005) metaphor, this thematic issue explores whether the recent upsurge of solidarity has merely been a wave, forcefully hitting the beach before vanishing back into the sea, or if it has actually changed the structure of the shoreline.

\section{Contributions}

The articles assembled here address four sites of change: the dynamics between civil and state actors involved in refugee protection; the gradual politicisation of individual volunteers and organisations; the reproduction of pre-existing cultural imaginaries; and the potential of cities to foster new forms of solidarity. These contributions adopt a wide range of methodological and theoretical approaches and include case studies from across Europe. Despite their differences, most share a focus on the impact of civil initiatives and NGOs on the relations between established and outsiders.

The first six articles examine whether and how the rise of new volunteering initiatives have altered the relation between civil and state actors. Two general trends emerge, which largely corroborate earlier findings. On the one hand, some civil initiatives have been (partly) 
co-opted by state actors to complement their policies. While this process of institutionalisation has led to gradual adaptations and policy changes in some cases, it also harbours the risk of making it easier for governments to neglect their responsibilities (van Dyk \& Misbach, 2016; Vandevoordt \& Verschraegen, 2019). By invisibilising the harshest consequences of "organised non-responsibility" (Pries, 2018), civil initiatives may help to safeguard governments from moral criticism and indirectly weaken political support for more stringent action. On the other hand, however, offering civil support to refugees can create a powerful political momentum (Feischmidt \& Zakarias, 2019; Vandevoordt, in press). Especially in contexts where governments have put in place more restrictive migration policies designed to deter immigration, civil actors have entered in conflict-ridden, highly politicised relations with the state.

In their contribution to this issue, Larruina, Boersma and Ponzoni (2019) note that the work of civil actors has brought about a reconsideration of the challenges of receiving refugees. Based on qualitative research with Dutch organizations working with refugee reception and integration, they observe a shift in the broader organizational ecology of Dutch refugee reception. While the system of refugee reception before the asylum crisis was mostly dominated by governmental organizations, the crisis enabled a broader participation of civil society organizations, as well new volunteering initiatives by citizens. It also created more space for active participation of refugees themselves. This change occurred mainly because of a focus on local rather than central government initiatives and because stakeholders sought to network, collaborate, and share best practices.

Fleischmann (2019) also highlights how the long summer of migration reordered the relationships between governmental actors and civil society active in the reception of asylum seekers. Based on ethnographic work in Germany, she shows how representatives from local to regional authorities emphasized the value and significance of citizen commitment, but also introduced numerous programmes and efforts seeking to order and influence volunteering with refugees. These manifold interventions, Fleischmann suggests, led to the institutionalization of 'civil society' vis-à-vis 'the state', making committed citizens complicit in the governance of asylum seekers. She warns however for too quick and simple evaluations: while the governmental appreciation of volunteers may have led to increased control it also opened up new avenues for forms of civic solidarity with refugees.

Haselbacher (2019) notices as well that local civic engagement can induce change and transformation but is also riddled with ambivalence. In her contribution she examines how the opening of new refugee accommodation centres in small and predominantly rural municipalities in Austria, has encouraged citizens and local policy makers to get active and establish local support initiatives. Such local civic engagements contrast the more restrictive national paradigms and can counteract hostile activism demanding the exclusion of asylum seekers and questioning the existence of the asylum centre. Yet, as most local solidarity claims are interwoven with exclusionary narratives on integration, deservingness and performance, they leave dominant subject categories unchallenged. In their analysis of a large popular education program directed to adult asylum seekers in Sweden, Mešić, Dahlstedt, Fejes and Nyström (2019) focus on organized civil society-in this case study associations and folk high schools-and how they mobilized their resources and connections to promote the social inclusion of refugees in Sweden.

Two other articles focus primarily on different factors shaping the relation between civil and state actors. Drawing on findings from qualitative research carried out with refugee-supporting organisations in three different locations in Wales, Guma, Woods, Yarker and Anderson's (2019) article analyses the intensity and variation of civil society response in each of these localities, reinforcing or altering existing place-frames and contexts. Vandevoordt (2019a) highlights the importance of local circumstances for understanding the evolution of volunteering and civil society support for refugees. By comparing two civil initiatives in different regions in Belgium, he shows how the political environment in which these initiatives emerged, and the social backgrounds of their leading members shaped their strategies for inducing cultural and political change, and their ability to institutionalise themselves. In the case of Flanders, long-term neo-liberalisation of integration and state-civil society relations both created an opportunity to mobilise and closed the possibility of cooperative inclusion. In Brussels, by contrast, the super-diverse composition of the city, its constant reemergence as a site of crisis and the availability of multilevel opportunity structures allowed its largest citizen initiative to grow into a powerful political actor.

The second set of articles explores changes on a different level: the de/politicisation of individual volunteers and organisational practices. On the one hand, several authors reaffirm what others have suggested earlier (Fleischmann \& Steinhilper, 2017): as 'ordinary' citizens become personally involved with refugees, they become more aware of the social and political causes to refugees' daily struggles and, in some cases, they take social and political action accordingly. On the other hand, these personal engagements also tend to reproduce race- and gender-infused power asymmetries between those that that help and those that are being helped (Braun, 2017).

Drawing on Austrian and German case studies respectively, Schmid (2019) and Stock (2019) show how female volunteers engage in a feministic ethics of care which opens up alternative ways of thinking about difference and the politics of integration. Drawing on case studies from 4 different municipalities in Germany, Schmid describes how her volunteers gradually adapted their views on diversity and cultural difference. Some of the volunteers consciously showed their support to 
refugees in public, trying to convey to their environment that refugees should not be seen as a threat. Similarly, Stock conducted qualitative interviews with refugees and volunteers participating in a buddy-scheme in Austria. She found that these buddy-relations sometimes reinforced exclusionary perspectives on who 'deserves' to be helped and who does not. Volunteers were able to partly overcome these differences, however, through practices of 'kinning': by considering each other as kind, on familial terms, through an ethics of care. While this reproduced inequalities, it also resulted in volunteers' unconditional intention to 'stand with' migrants vis-à-vis migration policies. In addition, volunteers became more aware and often more critical towards migration policies, and for the first time joined manifestations and other collective actions.

Drawing on an ethnographic case study in the hub in the Milan-central train station, Sinatti (2019) arrives at a similar conclusion. Situating her argument within critical humanitarian studies, she acknowledges humanitarianism's tendencies to de-politicise suffering and reduce those in need to instances of bare life, robbed of social and political subjectivity. Through direct contact with refugees, however, Sinatti argues that volunteers obtain more insights into the daily lives and aspirations of migrants, which raises their awareness and leads them to identify as activists, rather than volunteers. By doing so, they engage in a 'politics of life' which aspires to an alternative, more inclusive social order.

In his analysis of the Austrian 'Godparenthood' mentoring programme for unaccompanied minors, Raithelhuber (2019) also notices a growing political awareness of participating volunteers, as well as more chances for young refugees through the support they acquire. Yet, at the same time the Austrian mentoring scheme does not turn around existing discriminatory policies, as it confirms the exclusion criteria established by the state and hence reproduces the differential inclusion of refugees. Schmid, Evers and Mildenberger (2019) point to a similar co-existence of politicizing and depoliticizing processes in their study of local support movement for refugees in Heidelberg, Germany. Whilst volunteers and activists take positions in the country-wide controversial political debates on refugees, their practical local action is often restricted to helping out refugees.

Thirdly, a couple of contributions highlight how the asylum crisis reproduces pre-existing cultural imaginaries. Vieten and Murphy (2019) analyse how Northern Ireland's legacy of conflict and sectarianism frames the imagination of newcomers and the experiences of asylum seekers and refugees. Wallaschek (2019) takes on the question of how refugee solidarity is framed in two German and two Irish qualitative newspapers. Drawing on discourse network methods he concludes that pro-solidarity is a common frame, but is conceived of very differently by the different actors in both countries. Wallaschek's analysis hence demonstrates how partisan journalism - the political orientation of media outlets influencing their coverage of public debates-has persisted during Europe's asylum crisis.

A fourth set of contributions explore cities' potential to foster new forms of solidarity. These contributions build on a growing literature documenting the rise of sanctuary cities in North-America and solidarity cities in Europe (Bauder \& Gonzalez, 2018) or conceptualising cities as common spaces where new political subjectivities can be formed.

Agustín and Jørgensen (2019) argue that national policies are often more exclusionary towards immigrants, whereas municipalities-especially those of super-diverse metropolises-are confronted with the human consequences of these policies and hence favour more inclusive, pragmatic strategies. Agustín and Jørgensen explore the specific case of Barcelona as an example of institutional solidarity, where citizen and municipal governments join arms in advocating for more inclusive migration policies vis-à-vis the national Spanish government. In addition, Barcelona has been at the forefront of setting up European networks of solidary cities. Drawing on expert interviews and document analysis, Heimann, Müller, Schammann and Stürner (2019) conceptualise these intercity networks as transmunicipal solidarity, which they distinguish from traditional forms of solidarity. They document how cities like Barcelona, Naples, Bonn and Cologne are connected through networks such as Eurocities, Integration cities and Solidarity Cities. Through these non-hierarchical, polycentric networks, they pressure national governments, lobby the EU and stimulate mutual capacity-building.

Yet cities can also serve as common spaces where refugees and activists build new political subjectivities outside of institutional politics. In his case study of Thessaloniki, Tsavdaroglou (2019) describes how the closing of the Greek-Macedonian border and the policy of containing refugees in isolated, poorly equipped camps attracted a large group of international activists. Together with refugees, they set up direct democracy assemblies, established infrastructures of social support, squatted buildings and organised demonstrations. Drawing on notions of the right to the city, common space and autonomy of migration, Tsavdaroglou documents how they established the right to visibility, and used the city as a common space where transnational solidarities were forged. In this sense, bordering cities in particular seem to harbor potential for mobilising and reinforcing solidarity (cf. Bontemps, Makaremi, \& Mazouz, 2018; Vandevoordt, 2019a).

\section{Conclusion}

This thematic issue documents how the upsurge of refugee solidarity contains potential pathways to more pertinent change. First, there is the possibility of institutionalisation and changing policies from within, sometimes even changing the whole ecology of state and civil society. How this plays out ultimately depends on 
favourable political opportunity structures on different governance levels, the social backgrounds of individual members and the networks between organisations. Yet, civil initiatives for refugees also harbour the risk of substituting government action and changing the nature of citizen engagement. Second, refugee solidarity has the potential of politicising individual volunteers, although it is not always capable to counteract the reproduction of race- and gender-infused power asymmetries. And third, cities harbour specific potential for fostering solidarity, both through institutional alliances and through grassroots' claims of 'the right to the city'.

\section{Acknowledgments}

We would like to thank all contributors for their dedicated work on this thematic issue, as well as the many reviewers, for skilfully commenting on our sixteen manuscripts and encouraging authors to improve their articles further. We extend our gratitude to the editors of Social Inclusion for their patience and support while collaborating on this issue. We would also like to thank the Flemish Research Council (FWO) and the Swiss Federal Bureau of Foreign Affairs for providing the financial support which enabled us to edit this volume.

\section{References}

Agustín, O. G., \& Jørgensen, M. B. (2019). Solidarity cities and cosmopolitanism from below: Barcelona as refugee city. Social Inclusion, 7(2), 198-207.

Bauder, H., \& Gonzalez, D. A. (2018). Municipal response to 'illegality': Urban sanctuary across national contexts. Social Inclusion, 6(1), 124-134.

Bontemps, V., Makaremi, C., \& Mazouz, S. (Eds.). (2018). Entre accueil et rejet ce que les villes font aux migrants [Between reception and rejection: What cities do for/to migrants]. Lyon: Le passager clandestin.

Braun, K. (2017). Decolonial perspectives on charitable spaces of "welcome culture" in Germany. Social Inclusion, 5(3), 38-48.

Della Porta, D. (Ed.). (2018). Solidarity mobilizations in the 'refugee crisis': Contentious moves. New York, NY: Springer.

Feischmidt, M., \& Zakarias, A. (2019). Politics of care and compassion: Civic help for refugees and its political implications in Hungary. A mixed-methods approach. In M. Feischmidt, L. Pries, \& C. Cantat (Eds.), Refugee protection and civil society in Europe (pp. 59-99). London: Palgrave MacMillan.

Feischmidt, M., Pries, L., \& Cantat, C. (Eds.). (2019). Refugee protection and civil society in Europe. Basingstoke: Palgrave Macmillan.

Fleischmann, L. (2019). Making volunteering with refugees governable: The institutionalization of 'civil society' as a responsible actor in the German welcome culture. Social Inclusion, 7(2), 64-73.

Fleischmann, L., \& Steinhilper, E. (2017). The myth of apo- litical volunteering for refugees: German welcome culture and a new dispositif of helping. Social Inclusion, 5(3), 17-27.

Guma, T., Woods, M., Yarker, S., \& Anderson, J. (2019). "It's that kind of place here": Solidarity, place-making and civil society response to the 2015 refugee crisis in different localities in Wales, UK. Social Inclusion, 7(2), 96-105.

Haselbacher, M. (2019). Solidarity as a field of political contention: Insights from local reception realities. Social Inclusion, 7(2), 74-84.

Heimann, C., Müller, S., Schammann, H., \& Stürner, J. (2019). Challenging the nation-state from within: The emergence of transmunicipal solidarity in the course of the EU refugee controversy. Social Inclusion, 7(2), 208-218.

Hess, S., Kasparek, B., Kron, S., Rodatz, M., Schwertl, M., \& Sontowski, S. (2016). 'Der lange Sommer der Migration: Krise, Rekonstitution und ungewisse Zukunft des Europäischen Grenzregimes' [The long summer of migration: Crisis, reconstitution and uncertain future of the European border regime]. In S. Hess, B. Kasparek, S. Kron, M. Rodatz, M. Schwertl, \& S. Sontowski (Eds.), Der lange Sommer der Migration: Grenzregime III [The long summer of migration: Border regime III] (pp. 6-24). Berlin and Hamburg: Assoziation A.

Larruina, R., Boersma, K., \& Ponzoni, E. (2019). Responding to the Dutch asylum crisis: Implications for collaborative work between civil society and governmental organizations. Social Inclusion, 7(2), 53-63.

Mešić, N., Dahlstedt, M., Fejes, A. \& Nyström, S. (2019). Use-values for inclusion: Mobilizing resources in popular education for newly arrived refugees in Sweden. Social Inclusion, 7(2), 85-95.

Pries, L. (2018). Refugees, civil society and the state. European experiences and global challenges. Cheltenham: Edward Elgar Publishing.

Raithelhuber, E. (2019). Rearranging differential inclusion in the light of universalistic principles. How civic solidarity for 'unaccompanied refugees' is organized through loose coupling in mentorship. Social Inclusion, 7(2), 149-164.

Schmid, S. (2019). Taking care of the other: Visions of a caring integration in female refugee support work. Social Inclusion, 7(2), 118-127.

Schmid, V., Evers, A., \& Mildenberger, G. (2019). More or less political: Findings on a central feature of local engagement for refugees in Germany. Social Inclusion, 7(2), 165-175.

Sinatti, G. (2019). Humanitarianism as politics: Civil support initiatives for migrants in Milan's Hub. Social Inclusion, 7(2), 139-148.

Stock, I. (2019). Buddy-schemes between migrants and volunteers in Germany: Transformative potential in an unequal relationship? Social Inclusion, 7(2), 128-138.

Sutter, O., \& Youkhana, E. (2017). Perspectives on the 
European border regime: Mobilization, contestation, and the role of civil society, Social Inclusion, 5(3), 1-6.

Tarrow, S. (2005). Power in movement: Social movements and contentious politics. Cambridge: Cambridge University Press.

Tsavdaroglou, C. (2019). Reimagining a transnational right to the city: No border actions and commoning practices in Thessaloniki. Social Inclusion, 7(2), 219-229.

Vandevoordt, R. (2019a). Eroding rights, crafting solidarity? Shifting dynamics in the state-civil society nexus in Flanders and Brussels. Social Inclusion, 7(2), 106-117.

Vandevoordt, R. (in press). Subversive humanitarianism. Rethinking the politics of refugee solidarity through grassroots initiatives. Refugee Survey Quarterly.
Vandevoordt, R., \& Verschraegen, G. (2019). Subversive humanitarianism and its challenges: Notes on the political ambiguities of civil refugee support. In M. Feischmidt, L. Pries, \& C. Cantat (Eds.), Refugee protection and civil society in Europe (pp. 101-128). Basingstoke: Palgrave Macmillan.

Van Dyk, S., \& Misbach, E. (2016). Zur politischen Ökonomie des Helfens [On the political economy of helping]. PROKLA, 46(183), 205-227.

Vieten, U., \& Murphy, F. (2019). The imagination of the other in a (post-)sectarian society: Asylum seekers and refugees in the divided city of Belfast. Social Inclusion, 7(2), 176-186.

Wallaschek, S. (2019). The discursive appeal to solidarity and partisan journalism in Europe's migration crisis. Social Inclusion, 7(2), 187-197.

\section{About the Authors}

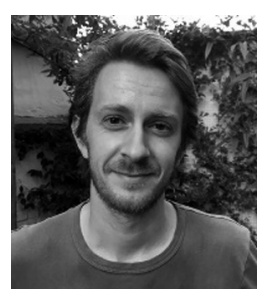

Robin Vandevoordt is a cultural and political sociologist whose research interests are in forced migration, humanitarianism, civil solidarity, and European migration policies. He is currently an Early Career Fellow at Oxford University's Refugee Studies Centre, where he continues his ethnographic work with civil initiatives supporting refugees.

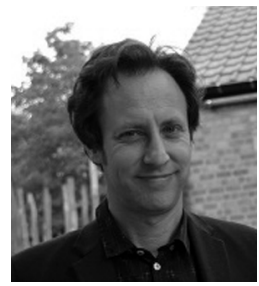

Gert Verschraegen is Associate Professor of Sociology at the University of Antwerp (Belgium), where he also serves as the Head of the department of sociology. His main research interests are in social theory, cultural sociology, the sociology of science and knowledge and the sociology of human rights and humanitarianism. His work has appeared in Poetics, Citizenship Studies, Journal of European Social Policy, Journal of Social Policy, Futures, Innovation, Journal of Law and Society, Time and Society, and many other journals. A recent book is Divercities: Dealing with Diversity in Deprived and Mixed Neighbourhoods (2018, Policy Press, edited with Stijn Oosterlynck). His current research projects include "The European Refugee Controversy as a Cosmopolitan Crisis: The Rise, Spread and Development of New Moral Imaginaries and Movements" and "Making and Unmaking Muslim Identities. Symbolic Boundary Work and Islam in Flanders". 